\title{
BADAN USAHA KOPERASI DAN BADAN USAHA NON KOPERASI (Studi Komparatif)
}

\author{
Itang \\ IAIN Sultan Maulana Hasanuddin Banten
}

\begin{abstract}
Abstrak. Badan Usaha Koperasi dan Badan Usaha Non-Koperasi (Studi Komparatif). Tulisan ini ingin melihat dari dekat badan usaha koperasi dan badan usaha non koperasi. Koperasi merupakan soko guru perekonomian Indonesia yang mesti dipertahankan keberadaannya, pada kenyataannya badan usaha koperasi ini tidak eksis keberadaannya seperti badan usaha non koperasi. Adapun perbedaannya adalah dapat dilihat dari beberapa aspek, yaitu: a. Aspek kelembagaan, yaitu: 1. Dilihat dari segi keanggotaan, 2. Dilihat dari rapat anggota, 3. Dilihat dari kepengurusan Direksi, 4. Dilihat dari Dewan Komisaris, 5. Dilihat dari manajemen, 6. Dilihat dari pendidikan. b. Aspek usaha, yaitu: 1. Tujuan, 2. Modal, 3. Badan Hukum, 3. Aspek Keuntungan.
\end{abstract}

Kata Kunci: Badan Usaha, Koperasi dan non Koperasi

Abstrak. The Comparative Study on Cooperative Enterprise and Non-Cooperative Enterprises. This paper would like to learn deeply on cooperative business enterprise and non-cooperative enterprises. Cooperative is a pillar of the Indonesian economy. In fact cooperative business entity does not exist as non-cooperative enterprises. The difference can be found from several aspects; firstly, Institutional aspects (1. In terms of membership, 2. The meeting of members, 3. The management of the Board of Directors, 4. the Board of Commissioners, 5. The management, 6. The education) and secondly, Business aspects (1. The purpose, 2. The capital, 3. The legality, 3. Advantages).

Keywords: Enterprise, Cooperative dan Non-Cooperative. 


\section{Pendahuluan}

Pasal 33 ayat (1) UUD 1945 menyebutkan, bahwa "perekonomian disusun sebagai usaha bersama berdasarkan atas asas kekeluargaan. Ayat ini sekalipun tidak menyebutkan perkataan koperasi, namun asas kekeluargaan itu adalah koperasi. Hal ini lebih tegas dalam penjelasan pasal 33 UUD 1945 yang menyebutkan, bahwa: “Dalam pasal 33 tercantum dasar demokrasi ekonomi. Produksi dikerjakan oleh semua untuk semua di bawah pimpinan atau pemilikan anggota-anggota masyarakat. Kemakmuran masyarakatlah yang diutamakan, bukan kemakmuran orang seorang. Sebab itu perekonomian disusun sebagai usaha bersama berdasarkan kekeluargaan. Bangun perusahaan yang sesuai dengan itu ialah koperasi. Maka dalam tulisan ini ingin melihat lebih jauh perbedaan badan usaha koperasi dan badan usaha non koperasi (studi komperatif).

\section{Pengertian Koperasi}

Koperasi secara etimologi berasal dari bahasa inggris, yaitu "cooperation" (co=bersama, operation=bekerja). ${ }^{1}$ Jadi koperasi yaitu sama-sama bekerja menurut rencana yang sudah ditentukan kearah tujuan yang sudah ditetapkan. ${ }^{2}$ Sedangkan menurut terminologi, seperti yang dikemukakan para pakar yaitu:

1. Menurut Dr. Winardi, SE. Koperasi (coopetrative) adalah sejenis badan usaha dimana hanya terdapat satu hak suara pun setiap anggota, terlepas dari banyak sedikitnya uang yang dimasukkan olehnya badan usaha tersebut.

2. Menurut Prof. Dr. Syamsudin Mahmud. Koperasi adalah suatu perkumpulan dari orang-orang yang atas dasar persamaan derajat sebagai manusia dengan tidak membedakan haluan agama atau politik dengan sukarela masuk untuk memenuhi kebutuhan bersama yang bersifat kebendaan atas tanggungan bersama.

3. Menurut Roelijan Soedarsono, dkk. Koperasi adalah kumpulan yang memungkinkan orang-orang bekerja atas dasar sukarela untuk menyelenggarakan produksi, pembelian dan penjualan barang atau jasa, yang ditujukan untuk memenuhi kebutuhan para anggota.

4. Menurut Dr. Fay (1908). Koperasi adalah suatu perserikatan dengan tujuan berusaha bersama yang terdiri atas mereka yang lemah dan diusahakan selalu dengan semangat tidak memikirkan diri sendiri sedemikian rupa, sehingga 
Itang: Badan Usaha Koperasi...

masing-masing sanggup menjalankan kewajibannya sebagai anggota dan mendapat imbalan yang sebanding dengan pemanfaatan mereka terhadap organisasi. $^{3}$

5. Menurut Margono Djojohadijoesomo. Koperasi ialah perkumpulan manusia seorang-seorang yang dengan sukanya sendiri hendak bekerja sama untuk memajukan ekonominya. ${ }^{4}$

6. Menurut Prof. Marvin A. Schaars. Koperasi adalah suatu badan usaha yang secara sukarela dimiliki dan dikendalikan oleh anggota yang adalah juga pelanggannya dan dioperasikan oleh mereka dan untuk mereka nirlaba atau atas dasar biaya.

7. Menurut Paul Hubert Casselman. Koperasi adalah suatu sistem ekonomi yang mengandung unsur sosial. 5

8. Menurut Drs. Arifinal Chaniago. Koperasi adalah suatu perkumpulan yang beranggotakan orang-orang atau badan-badan, yang memberikan kebebasan masuk dan keluar sebagai anggota; dengan bekerja sama kekeluargaan jasmaniyah para anggotanya. ${ }^{6}$

9. Menurut Sugimun, MD. Dkk. Koperasi adalah sisterm Perekonomian yang bisa berhasil meletakkan sendi yang kuat untuk memperbaiki Perekonomian rakyat.7

10. Menurut Sugimun, MD. Koperasi adalah suatu perkumpulan yang memungkinkan beberapa orang atau badan (badan Hukum) dengan jalan bekerja sama atas sukarela menyelenggarakan suatu pekerjaan untuk memperbaiki kehidupan anggota-anggotanya. ${ }^{8}$

11. Menurut Ir. Kalsan A. Tohir. Koperasi adalah persekutuan orang, bukan persekutuan modal seperti N.V. dalam koperasi orang yang dipandang penting, modal hanya sebagai alat, menjadi hamba. Lain halnya dengan N.V. Misalnya. Dalam N.V. Modal yang dipandang terpenting, orang nomor dua. ${ }^{9}$

12. Dalam buku pengetahuan perkoperasian yang diterbitkan oleh departemen Koperasi, mengemukakan arti koperasi sebagai berikut: koperasi dikenal sebagai perkumpulan orang-orang yang secara sukarela mempersatukan diri untuk mencapai kepentingan-kepentingan ekonomi, atau menyelenggarakan usaha bersama melalui pembentukan suatu perkumpulan yang diawasi secara demokratis. ${ }^{10}$ 
Islamiconomic: Jurnal Ekonomi Keuangan dan Bisnis Islam Vol.7 No.1 Januari - Juni 2016

13. Menurut Sri-Edi Swasono. Koperasi adalah bentuk usaha yang tidak saja menampung tetapi juga mempertahankan serta memperkuat identitas dan budaya bangsa Indonesia. Kepribadian bangsa bergotong royong dan kolektivan akan tumbuh subur didalam koperasi. Selanjutnya koperasi sendiri akan lebih terbangun dan lebih menguat. ${ }^{11}$

14. Menurut Undang-undang Nomor 25 tahun 1992. Koperasi adalah badan usaha yang beranggotakan orang-orang atau badan hukum koperasi dengan melandaskan kegiatan berdasarkan prinsip koperasi sekaligus sebagai gerakan ekonomi rakyat berdasar atas asas kekeluargaan. ${ }^{12}$

Memperhatikan pendapat para pakar diatas, definisi tersebut mengandung unsur-unsurunsur sebagai berikut:

1. Perkumpulan koperasi bukan merupakan perkumpulan modal (bukan Akumulasi modal), akan tetapi persekutuan sosial.

2. Sukarela untuk menjadi anggota, netral terhadap aliran dan agama.

3. Tujuannya mempertinggi kesejahteraan jasmaniyah anggota-anggota dengan kerja sama secara kekeluargaan. ${ }^{13}$

4. Bahwa dengan kerja sama itu, manusia akan lebih mudah mencapai apa yang diinginkan.

5. Bahwa pendirian dari suatu koperasi mempunyai pertimbangan-peritmbangan ekonomis.

6. Mengandung unsur demokrasi

7. Mengandung unsur sosial

8. Mengandung unsur tidak semata-mata mencari keuntungan. ${ }^{14}$

Menurut Undang-undang Nomor 25 tahun 1992 tentang pokok-pokok perkoperasian, organisasi koperasi mempunyai ciri-ciri yang nampak, yaitu: 15

a. Bahwa koperasi Indonesia adalah kumpulan orang-orang dan bukan kumpulan modal. Pengaruh dan penggunaan modal dalam koperasi Indonesia tidak boleh mengurangi makna dan tidak boleh mengaburkan pengertian koperasi Indonesia sebagai perkumpulan modal. Ini berarti bahwa koperasi Indonesia harus benarbenar mengabdikan kepada perkumpulan dan bukan kepada kebendaan. 
Itang: Badan Usaha Koperasi...

b. Bahwa koperasi Indonesia bekerja sama, bergotong royong berdasarkan persamaan derajat, hak dan kewajiban yang berarti koperasi adalah dan seharusnya merupakan wadah demokrasi ekonomi dan sosial. Karena dasar demokrasi ini maka harus dijamin benar-benar bahwa koperasi adalah milik para anggota sendiri dan pada dasarnya harus diatur serta disusun sesuai dengan keinginan para anggota yang berarti bahwa hak tertinggi dalam koperasi terletak pada rapat anggota.

c. Bahwa segala kegiatan koperasi Indonesia berdasarkan atas kesadaran para anggota. Dalam koperasi tidak boleh dilakukan paksaan,ancaman, intimidasi dan campur tangan dari pihak lain yang tidak ada sangkut-pautnya dengan soal-soal interen koperasi.

d. Bahwa tujuan koperasi Indonesia harus benar-benar merupakan kepentingan bersama dari para anggotanya dan tujuan itu dicapai berdasarkan karya dan jasa yang disumbangkan para anggota sesuai dengan besar kecilnya karya dan jasanya harus dicerminkan pula dalam hal pembagian pendapatan dalam koperasi.

Kerja sama dalam masyarakat telah nampak wujudnya dalam suatu jaringan system yang lebih kompleks. Bentuk-bentuk ikatan persekutuan hidup telah berkembang dan menjadi lebih beragam. Kini kerja sama disamping memenuhi kebutuhan menjaga kelangsungan hidup dan rasa aman, juga untuk memperoleh kasih sayang dan persahabatan seperti dalam keluarga dan paguyuban, juga telah digunakan untuk mencapai tujuan-tujuan tertentu yang diinginkan, seperti nampak pada bentuk-bentuk organisasi yang resmi. ${ }^{16}$

Kerja sama dalam lapangan ekonomi bagi masyarakat sudah sangat berkembang. Apalagi masa sekarang ini, bahkan ada yang sudah menjadi masyarakat modern. Perkembangan tersebut bukan saja ragam kegiatannya, tetapi jangkauan lingkupnya yang cukup luas. Kerja sama terjalin dalam sistem pembagian kerja yang rimit pada setiap lapangan kegiatan ekonomi, seperti pertanian, industri, perdagangan dan lain-lain. Disamping jaringan antar lapangan ekonomi, antar kelompok, antar organisasi, antar daerah, bahkan dalam lingkup internasional. Secara ekonomis, umat manusia dipelosok bumi itu saling membutuhkan, saling bergantung satu sama lain. ${ }^{17}$ 
Islamiconomic: Jurnal Ekonomi Keuangan dan Bisnis Islam Vol.7 No.1 Januari - Juni 2016

Manusia, disamping naluri untuk bekerja sama, juga menyandang naluri lainnya. ${ }^{18}$ Umpamanya saja naluri untuk bersaing yang mewarnai kehidupan sosial politik, olah raga dan ekonomi. Harus diakui, kemajuan dunia yang amat pesat, antara lain karena semangat untuk bersaing, berlomba untuk mencapai prestasi dan kemajuan setinggi-tingginya. Semangat persaingan ini, disamping hasil-hasil yang positif dan bermanfaat, juga memiliki akibat samping yang merugikan atau bahkan mencemaskan seluruh umat manusia. Umpamanya saja dalam perlombaan nyuklir, atau dalam lapangan ekonomi persaingan bebas akan mematikan yang lemah. Dalam tata kehidupan ekonomi yang semata-mata yang dilandasi oleh semangat persaingan, maka sebagian rakyat kecil yang lemah seperti petani, nelayan, pedagang kecil, Pengrajin dan lain-lain. Akan tertinggal dari arus kemajuan karena tidak memiliki kemampuan untuk bersaing dengan golongan lain yang lebih kuat.

Guna mencapai tujuan luhur seperti tercantum dalam pancasila dan Undangundang dasar 1945, yaitu mewujudkan kemakmuran bagi seluruh rakyat Indonesia, maka tat kehidupan ekonomi harus dikembangkan atas dasar semangat kerja sama dan kekeluargaan. Golongan masyarakat lemah di desa dan di kota yang merupakan sebagian besar rakyat Indonesia perlu diajak, diikutsertakan serta aktif dan diberikan kesempatan yang lebih luas untuk membangun dirinya melalui koperasi. ${ }^{19}$

\section{Sejarah perkembangan Koperasi}

Sejarah perkembangan gerakan koperasi ini penulis uraikan sesuai dengan asal berdirinya koperasi itu, sehingga sampai pada perkembangan koperasi di Indonesia. Pada bahasan ini diuraikan perkembangan koperasi di luar negeri sampai perkembangannnya di Indonesia.

\section{A. Perkembangan Koperasi di Luar Negeri}

Keberadaan koperasi di luar negeri merupakan titik awalnya adanya usaha kerja sama sekelompok orang untuk mencapai kesejahteraan bersama. Sehingga tidak mustahil apabila perjuangannya untuk mencapai tujuan itu melalui proses yang cukup lama. Karena perjuangan yang dilakukan didasari rasa kebersamaan, rasa kesetiakawanan, kegigihan dan kesabaran dari para anggota, maka kemajuan demi kemajuan dapat diraih dan sampai sekarang koperasi merupakan badana usaha yang 
Itang: Badan Usaha Koperasi...

terkenal di dunia, diantaranya adalah koperasi Rochdale di Inggris dan koperasi Raiffeisen, serta Sculze di Jerman. Walaupun koperasi-koperasi tersebut berkembang di Negara yang berbeda, tetapi mempunyai tujuan maupun prinsip dasar yang sama, yaitu ingin memperbaiki perekonomian dan kesejahteraan masyarakat. Perkembangan gerakan koperasi ini diawali dari Negara Inggris.

\section{Gerakan Koperasi di Inggris}

Inggris terkenal sebagai tanah kelahiran perkumpulan koperasi, yaitu pada tanggal 12 Desember $1884 .^{20}$ pada mulanya 28 orang pekerja pabrik tekstil dengan kemampuan yang terbatas membentuk perkumpulan dan mendirikan sebuah toko kecil. Didirikannya toko/kedai ini bertujuan untuk memenuhi kebutuhan sehari-hari dari apra anggota. Dilakukan dengan penuh ketekunan, kejujuran, dan rajin serta rasa kesetiakawanan dari para anggota, maka sudah sewajarnya jika koperasi Rochdale mengalami kemajuan yang pesat. Usaha-usaha yang dijalankan dari toko kecil menjadi usaha mendirikan perumahan, mendirikan pabrik serta mengadakan pengetahuan para angggota dan pengurusnya. Perkembangan dan kemajuan koperasi Rochdale mengakibatkan tumbuhnya perkumpulan koperasi yang tidak sedikit jumlahnya, sehingga pada tahun 1852 di Inggris terdapat 100 perkumpulan koperasi.

Keberhasilan koperasi Rochdale yang gilang-gemilang itu terletak pada dasardasar atau asas-asas koperasi yang diletakkan dan ditanamkannya kepada anggotaanggotanya. Harga diri dan kesadaran berkoperasi yang tinggi koperasi Rochdale berhasil mengatasi segala rintangan dan hambatan. Dasar-dasar atau asas-asas koperasi yang berhasil disusun oleh koperasi Rochdale sampai sekiarang dikenal dengan nama "Rochdale Principles". Perkumpulan itu kemudian diakui sebagai koperasi konsumsi yang pertama di dunia. ${ }^{21}$ adapun asas-asas atau dasar-dasar koperasi Rochdale yang terpenting adalah: ${ }^{22}$

a. Masuk dan berhenti menjuadi anggota koperasi atas dasar sukarela.

b. Satu anggota satu hak suara

c. Koperasi netral terhadap agama dan politik

d. Pembelian dan penjualan secara tunai

e. Pembagian keuntungan koperasi menurut jasa anggota-anggota

f. Harga penjualan disamakan dengan harga pasar setempat 
Islamiconomic: Jurnal Ekonomi Keuangan dan Bisnis Islam Vol.7 No.1 Januari - Juni 2016

g. Kualitas atau mutu, ukuran dan timbangan barang-barang koperasi harus dijamin

h. Penyelenggaraan usaha pendidikan bagi anggota-anggota koperasi

2. Gerakan Koperasi di Jerman

Koperasi konsumsi atau koperasi pemakaian lahir di Inggris, sedangkan koperasi simpan pinjam atau koperasi kredit lahir di Jerman pada tahun 1882 atas prakarsa seorang pamong raja, walikota F.W. Raeffeisen. ${ }^{23}$

Pada permulaan abad 19 perekonomian di Jerman masih bersifat agraris. Ketika itu tanah sebagian besar dimiliki oleh tuan tanah sehingga nasib petani dapat diperlakukan semena-mena. Setelah adanya Undang-undang agrarian tahun 1807 maka diantara petani sudah bebas itu pergi ke kota menjadi buruh. Setelah dikota nasibnya tidak berubah, tenaganya diperas demi keuntungan kaum kapitalis. Keadaan waktu itu, baik petani maupun buruh banyak termakan riba, karena ekonominya sangat menyedihkan sehingga muncul para budiman yang mencoba membebaskan kaum tani dan buruh tani. Diantaranya adalah Frederich Wilhelm Raiffeisen (1818-1888) dan Herman Schulze Delitzsh. Keduanya pada saat yang hampir sama dan dasar usahanya adalah menolong diri sendiri dengan jalan bekerja sama.

1) F. Wilhelm Raiffeisen

Seorang walikota di Flammersfield, kemudian di Heldershof, F.W. Raiffeisen adalah penganjur koperasi simpan pinjam di kalangan petani. Didirikannya perkumpulan dimana 60 orang warga kota yang hanya bersedia mengumpulkan uang membeli tanah dan menjualnya kepada petani secara kredit pada tahun 1848. usahanya diperluas dengan memberi pinjaman uang.

Baru pada tahun 1864 usaha atas anjurannya itu bersifat koperasi. Cara kerja koperasi kredit modal Raiffeisen adalah:24

(1) Modal dikumpulkan dari tabungan petani sendiri

(2) Bekerja dikalangan Petani (sempit)

(3) Pengurus dipegang Petani sendiri dan tidak menerima gaji

(4) Usahanya lebih banyak bersifat ideal

(5) Penggunaan pinjaman uang diawasi 
Itang: Badan Usaha Koperasi...

(6) Hasil bunga dijamin modal.

2) Herman Schulze

Herman adalah ketua Komisi Perdagangan dalam parlemen, dimana usahanya juga menitik berat pada lapangan kredit guna memperbaiki kehidupan masyarakat, khususnya kaum buruh dan pedagang kecil.

Modal koperasi kreditnya agak berbeda dengan F.W Raiffeisen, yaitu dengan cara:

(1) Modal didapat dari siapapun

(2) Daerah kerja dikota (luas)

(3) Pinjaman jangka pendek dan diberikan kepada pedagang kecil

(4) Pengurus menerima gaji

(5) Keuntungan dibagi anggota.

\section{Gerakan Koperasi di Denmark}

Seperti di Jerman pada awal abad ke 18, keadaan perekonomian di Denmark bersifat agraris, dimana sebagian petani dalam keadaan miskin. Hal itu pula yang menyebabkan para budiman tergerak hatinya untuk merobah keadaan.

Pada tahun 1769 berdiri perkumpulan pertanian kerajaan Denmark, untuk mempelopori kebangkitan jiwa kaum tani. Selanjutnya pada tahun 1900, disusul dengan adanya perkumpulan petani kecil (small holders) yang wilayahnya sesuai dengan daerah pemerintahan, dengan nama "Parisher" dan "Counties". Kegiatan utamanya adalah 'pendidikan yang bertalian dengan pertanian dan peternakan. Sebelumnya pada tahun 1800 berhasil didirikan Bank Tabungan untuk pertanian (Sparekasse) oleh seorang dermawan bukan petani dan usaha ini berkembang pesat.

Adanya Undang-undang kewajibvan belajar (1814) telah mendorong perhatian dan rasa cinta generasi muda pada pertanian berhasil dipelihara. Hal itu terjadi karena di desa-desa kekurangan guru, sehingga diambil dari kalangan petani sendiri dan corak pelajarannya berkisar pada sektor pertanian.

Di Denmark hampir semua kegiatan ekonomi dilaksanakan dengan cara bekerja sama serta diselenggarakan oleh perkumpulan-perkumpulan koperasi. Demikian juga hampir semua hasil pertanian dan hasil industri Denmark diselenggarakan oleh 
Islamiconomic: Jurnal Ekonomi Keuangan dan Bisnis Islam Vol.7 No.1 Januari - Juni 2016

perkumpulan-perkumpulan koperasi. Sungguh pun industri menghasilkan dan memberikan pendapatan nasional yang terbesar bagi Denmark, namun pertanian memegang peranan yang amat penting didalam pembangunan industri Denmark.

Gerakan koperasi di Denmark itelah berhasil mencapai tingkat kemajuan yang mengagumkan. Karena hebatnya gerakan koperasi di Denmark ini, sehingga Bapak koperasi Indonesia, yakni Drs. Mohammad Hatta, memberi nama atau julukan kepada Denmark "Republik Koperatif" sungguhpun negeri Denmark adalah sebuah kerajaan.

Nama resmi negeri Denmark adalah "Kongeriget Denmark" artinya kerajaan Denmark, maka kedua nama julukan atau gelar ini yakni, "Republik Koperatif" dan "The Mecca of the cooperative world", memang tepat dan sesuai.

\section{Gerakan Koperasi di Swedia}

Pertumbuhan dan perkembangan koperasi di Swedia yang paling menonjol adalah koperasi konsumsi. Gerakan koperasi di Swedia berkembang maju dengan mantap. Terutama pada tahun 1899 koperasi-koperasi konsumsi bergabung ke dalam sebuah koperasi induk yang terkenal dengan nama "Kooperative Forbundet". Pada waktu itu banyak barang-barang kebutuhan sehari-hari seperti mentega, terigu, minyak nabati, dan lain-lainnya dimonopoli oleh perusahaan sejenis yang disebut kartel-kartel produsen. Kartel produsen ini adalah organisasi-organisasi perusahaan besar yang menghasilkan dan menjual barnag-barang sejenis. Para konsumen atau pemakai banyak yang mengalami kesulitan oleh kartel-kartel produsen yang memonopoli dan mempermainkan seenaknya sendiri barang-barang yang dibutuhkan pamakai atau konsumen yang tidak begitu mampu.

Pada tahun 1911 kooperative Forbundet telah menumbangkan dan melumpuhkan peranan monopoli kartel produsen mentega. Tahun 1924 kooperative Forbundet telah melumpuhkan serta menyingkirkan peranan monopoli kartel terigu. Tahun 1932 menghancurkan dan menyingkirkan peranan monopoli kartel minyak nabati dan selanjutnya menumbangkan serta menyingkirkan peranan monopoli kartel lainnya yaitu kartel produsen sepatu, dan bola lampu. Gerakan koperasi di Swedia makin lama makin maju serta berkembang. 
Itang: Badan Usaha Koperasi...

5. Gerakan Koperasi di Amerika Serikat

Amerika Serikat terkenal sebagai gembong atau biang Negara-negara kapitalis yang besar dan kuat, namun di negeri ini dapat juga berkembang usaha-usaha koperasi. Macam-macam koperasi yang berkembang di Amerika Serikat, yaitu:

1) Koperasi penjualan yaitu koperasi yang mendistribusikan segala macam hasil penjualan

2) Koperasi pembelian, ada dua jenis koperasi pembelian, yaitu:

a. Berusaha memperoleh atau memberi benih, pupuk, dan sebagainya untuk menmabah dan meningkatkan produksi pertanian

b. Bertindak mengusahakan barang-barang kebutuhan sehari-hari

3) Koperasi jasa atau koperasi pelayanan ialah koperasi yang menyelenggarakan berbagai macam usaha termasuk auransi, pelayanan kelistrikan, pelayanan kesehatan, pelayanan perumahan, pelayanan telepon terutama di desa-desa dan sebagainya.

Pada tahun 1960 Amerika Serikat tercatat kurang lebih 500 buah koperasi penghasil, 750 buah perkumpulan bank hipotek, 900 buah koperasi listrik desa, dan lain-lainnya. Di Amerika Serikat dikenal Credit Union. Pada perkembangan selanjutnya beberapa ribu Federal Credit Union ini membentuk federasi Asociation (CUNA) dengan maksud memperjuangkan kepentingan Union seluruhnya terutama kedudukannya dalam hukum.

Perkembangan credit union di Amerika Serikat berkat bantuan positif dari pemerintah dalam politik koperasi. Hal itu tercermin dalam federal credit union act yang mempunyai maksud:

1) Memberikan kedudukan tersendiri kepada koperasi dalam pergaulan hukum

2) Melindungi kepentingan masyarakat

3) Memlihara azas-azas koperasi

4) Memberi keistimewaan kepada koperasi

6. Gerakan Koperasi di Amerika Selatan, Afrika, Australia dan Selandia baru

Meskipun di Negara-negara Amerika Selatan atau Amerika latin rakyat sangat membutuhkan peningkatan taraf hidup serta perbaikan kemakmuran bersama, namun secara relatif perkembangan koperasi di Negara-negara ini tidak begitu 
Islamiconomic: Jurnal Ekonomi Keuangan dan Bisnis Islam Vol.7 No.1 Januari - Juni 2016

menonjol. Disebabkan beberapa faktor yaitu kekolotan, banyak rakyat masih buta huruf dan kurangnya modal. Namun beberapa di Negara Amerika Selatan menggalakkan koperasi.

Di Afrika gerakan koperasi belum begitu banyak dikenal. Kalaupun ada, keadaannya sangat sederhana dan menyesuaikan diri dengan tugas-tugas yang sederhana pula. Di Australia dan Selandia Baru perkumpulan-perkumpulan koperasi mirip keadaannya dengan keadaan perkumpulan koperasi di eropa dan mencapai hasil yang menggembirakan di dalam meringankan kesukaran-kesukaran dalam merintis daerah-daerah baru.

\section{Gerakan Koperasi di Uni Soviet}

Uni Soviet sebagai Negara sosialis/ komunis keadaan koperasinya berbeda. Perbedaan yang mendasar antara negeri-negeri yang lain adalah sistem pemerintah dan masyarakatnya. Pada umumnya ada tiga sikap gerakan koperasi mengenai asas atau dasar yang disebut political neutrality ini, yakni:

1) Ada yang acuh tak acuh terhadap politik

2) Ada yang netral terhadap politik

3) Ada yang tuirut aktif dalam gerakan politik

Gerakan koperasi Uni Soviet turut aktif dalam gerakan politik di negeri tersebut. Koperasi tidak dapat dan tidak boleh bersikap netral di dalam gerakan politik. Koperasi tidak boleh bersikap pasif dan acuh tak acuh terhadap persoalan-persoalan politik. Meskipun secara organisatoris koperasi tidak menggabungkan diri di dalam gerakan-gerakan atau partai komunis, secara idiologis koperasi harus menggabungkan diri serta berintegrasi dengan gerakan-gerakan komunis. Jadi koperasi bersatu dan berpadu dengan tujuan dan sasaran sosialisme/komunisme. Karena itu di Uni Soviet koperasi dibantu sepenuhnya oleh Negara dan didukung oleh partai komunis. Di Uni Soviet koperasi hnaya merupakan alat untuk menuju tercapainya masyarakat komunis. Ada pertanian kolektif yang dikenal dengan kolkhozi sebagai suatu bentuk koperasi, akan tetapi usaha koperasi ini sesungguhnya masih merupakan alat Negara Uni Soviet dan bukan koperasi di dalam arti yang murni atau sepeerti ditafsirkan orang di Negara-negara barat. 
Itang: Badan Usaha Koperasi...

8. Gerakan Koperasi di Jepang

Koperasi pertama kali didirikan di Jepang pada tahun 1990 bersamaan waktunya dengan Undang-undang koperasi industri kerajinan. ${ }^{25}$ Koperasi pertanian dan kredit di Jepang maju pesat, karena petani-petaninya dan masyarakat sudah lama mengenal dasar-dasar koperasi seperti mujin, hotokusya dan lain-lain.

Setelah zaman Tokugawa yaitu setelah tahun 1868, dikenal zaman moderen dimana Jepang mengenal peradaban barat. Shinagawa dan Hiragata adalah dua orang yang giat memasukkan koperasi kredit model raiffeisen. Berkat keduanya Undangundang koperasi tahun 1899 diterbitkan.

Peranan pemerintah Jepang sangat besar dalam perkembangan koperasi, yaitu dengan:

1) Dibebaskan koperasi dari beberapa pajak

2) Pinjaman koperasi tidak memakai tanggungan, sedang pinjaman dari pemerintah bahkan tanpa bunga

3) Pemerintah membeli barang hasil produksi koperasi

4) Koperasi sering menerima subsisdi pemerintah.

\section{Perkembangan Koperasi di Indonesia}

Di Indonesia koperasi telah lebih dikenal dari setengah abad yang lalu. Keberadaan koperasi di Indonesia sejak lahir sampai sekarang mengalami pasang surut terutama pada masa penjajahan. Koperasi tumbuh sekitar awal abad ke-19 merupakan hasil usaha yang spontan dari orang-orang yang mempunyai kemampuan terbatas. Dengan modal kebersamaan dan percaya diri koperasi makin berkembang, walaupun tidak sedikit halangan dan rintangan yang dihadapi. Berkat keuletan dan kesabaran serta motivasi untuk senantiasa berkembang, akhirnya koperasi mampu menjadi bagian yang integral dari perekonomian nasional, baik sebagai badan usaha maupun gerakan ekonomi rakyat. Perkembangan koperasi selanjutnya di bagi dalam beberapa periode, yaitu:

1. Perkembangan Koperasi Periode 1896-1908

Periode 1896-1908 negara Indonesia masih dalam cengkraman penjajah Belanda dan gerakan koperasi Indonesia belum dapat berkembang dengan baik. Pada tahun 1896 merupakan langkah awal dari gerakan koperasi di 
Islamiconomic: Jurnal Ekonomi Keuangan dan Bisnis Islam Vol.7 No.1 Januari - Juni 2016

Indonesia untuk berdiri yang dipelopori oleh Patih R. Aria Wiriaatmaja di Purwokerto. Bupati Purwokerto saat itu adalah E. Sieburgh mendukung gerakan koperasi ini. Kegiatan yang pertama kali dilakukan adalah mendirikan sebuah bank bantuan dan tabungan dengan tujuan membantu para pegawai negeri yang jatuh ke tangan lintah darat.

Pada tahun 1889, asisten residen E. Sieburgh diganti oleh De Wolf Van WEsterrode, asisten yang baru ini berkeinginan melanjutkan cita-cita E. Sieburgh yang mendukung gerakan koperasi yang didirikan R. Aria Wiriaatmaja. Bantuannya diwujudkan dengan merubah bank yang didirikan R. Aria Wiriaatmaja menjadi Poerwokertosche Hulp, Spaar en Landbourweredierbank (bank untuk bantuan, tabungan, dan kredit pertanian Purwokerto) yang cara kerjanya meniru koperasi Raiffeisen dan Schultze Delithch. Bantuan yang lain berupa 250 buah lumbung desa sebagai tempat untuk meminjamkan padi kepada rakyat, yang modalnya diambil dari zakat. Lumbung tersebut dikelola oleh kepala desa, juru tulis desa, dan Penghulu kampong. Gerakan koperasi yang didirikan R. Aria Wiriaatmaja ini berjalan dan berkembang dengan baik sampai lahirnya Budi Utomo tahun 1908.

2. Perkembangan Koperasi Periode 1908- 1927

Antara tahun 1908 dan 1913 Budi Utomo dan Serikat Dagang Islam, menggerakkan koperasi-koperasi rumah tangga dan koperasi toko kemudian menjadi koperasi konsumsi, selanjutnya koperasi batik. Pada tahun 1015 pemerintah Hindia Belanda mengetahui adanya bahaya dari perkumpulan koperasi ini, terutama sendi dasar demokrasi dan sendi persamaan hak dari koperasi sudah dikenal oleh rakyat. Dari keadaan ini pemerintah Hindia Belanda mengeluarkan peraturan koperasi Nomor 431 tahun 1915 yang isinya merupakan cara kerja koperasi, tetapi sebenarnya bersifat lebih membatasi gerak koperasi. Isinya sebagai berikut:

a. Anggaran dasarnya harus ditulis dalam bahasa Belanda, disahkan oleh notaries dan diumumkan oleh Berita Negara (dalam bahasa belanda) dan surat kabar Indonesia. 
Itang: Badan Usaha Koperasi...

b. Biayanya tinggi

c. Badan Hukum Eropa

Setelah peraturan tersebut berjalan lebih kurang 5 tahun, pemerintah Hindia Belanda menyadari abhwa koperasi merupakan alat untuk memperbaiki perekonomian rakyat, maka pada tahun 1920 dibentuk panitia/komisi koperasi. Dari hasil kerja panitia ini tersusun peraturan koperasi tahun 1972, lembaran Negara Nomor 91 yang berlaku bagi rakyat Indonesia dengan syarat yang lebih mudah dari peraturan Nomor 431 tahuin 1915.

3. Perkembangan koperasi Periode 1927-1942

Peraturan koperasi tahun 1927 lembaran Negara Nomor 91, merupakan Undang-undang koperasi yang pertama kali di Indonesia yang mewajibkan pemerintah untuk emmbina rakyat Indonesia kearah berkoperasi dengan jalan memberikan bimbingan dan penerangan.

Walaupun peraturan Nomor 91 tahun 1972 lebih mudah dan murah, gerakan koperasi belum dapat berkembang dengan baik. Pada tahun 1934 Departemen dalam Negeri merencanakan pembubaran urusan koperasi. Sejak tahun 1929 urusan koperasi berdiri sendiri dengan nama Jawatan Koperasi dan Perdagangan Dalam Negeri. Tahun 1936 Jawatan koperasi menganjurkan didirikannya pusat-pusat koperasi di seluruh Indonesia. Pada tahun 1940 koperasi memperluas kegiatannya dengan menempatkan pegawai di daerahdaerah.

4. Perkembangan Koperasi Periode 1942-1945

Sampai dengan akhir tahun 1939 jumlah koperasi telah mencpai 1712 dan yang terdaftar 172 dengan jumlah anggota 14.134 orang. Namun pada thaun 1942 Jepang mendarat di Indonesia. Badan-badan yang demokratis diubah menjadi alat-alat distribusi barang oleh tentara pendudukan yang disebut Kumiai. Akhirnya koperasi tidka mengalami kemajuan, kumiai sangat 
Islamiconomic: Jurnal Ekonomi Keuangan dan Bisnis Islam Vol.7 No.1 Januari - Juni 2016

merugikan dan menghancurkan perekonomian rakyat, sehingga rakyat tidak percaya lagi kepada koperasi.

5. Perkembangan Koperasi Periode 1945-1960

Pada tahun 1945 bersamaan dengan kemerdekaan Indonesia koperasi bangkit kembali dengan semangat baru; "melaksanakan Undang-undang dasar 1945 pasal 33 ayat 1. Dengan keyakinan bahw abentuk koperasi adalah organisasi yang sesuai dengan perekonomian secara kekeluargaan itu, maka pada tanggal 12 juli 1947 di Tasikmalaya (Jawa Barat) gerakan koperasi seluruh Indonesia mengadakan kongresny ay pertama dalam alam Indonesia merdeka.

Kongres koperasi Indonesia pada tahun 1953 dalam salah satu keputusannya telah menetapkan dan mengangkat Dr. Mohammad Hatta sebagai Bapak Koperasi Indonesia. Pada tahun 1958 mulai berlaku Undangundang koperasi No. 79/1958. Undang-undang ini yang pertama dibentuk, dengan berlandaskan UUD 45 pasal 33 ayat 1 . Sejak berlakunya Undangundang ini koperasi berkembang pesat di seluruh Indonesia.

6. Perkembangan Koperasi Periode 1960-1965

Pada tanggal 25-28 Mei 1960 diselenggarakan musyawarah kerja koperasi di Jakarta untuk merumuskan pola perkoperasian yang sesuai dengan peraturan pemerintah No. 60 tahun 1959 dan sebagai politik pemerintah di bidang perekoperasian.

Pada tahun 1960 dikeluarkan Intruksi Presiden No. 2 tahun 1960, sebagai usaha untuk meningkatkan perkembangan koperasi. Berlandaskan Inpres No. tahun 1960 dibentuk Badan Penggerak Koperasi (Bapenkop), yang anggotanya terdiri dari petugas-petugas pemerintah.

Pada bulan april 1961 diadakan seminar nasional koperasi pertama (munaskop I) di Surabaya untuk merumuskan pola perkoperasian secara nasional. Dewan Koperasi Indonesia (Dekopin) yang telah berdiri sejak tahun 1953 dibubarkan dan diganti dengan Kesatuan Organisasi Koperasi (KOKSI). 
Itang: Badan Usaha Koperasi...

Bulan agustus 1965 diadakan musyawarah nasional koperasi kedua (Munaskop II) di Jakarta.

7. Perkembangan Koperasi Periode 1966 sampai sekarang

Koperasi pada masa orde lama mengalami keadaan yang tidak menggembirakan sampai dengan tertumpasnya pemberontakan PKI. Setelah Jendral Soeharto memegang kekuasaan sejak 11 Maret 1965. keadaan koperasi mulai diadakan perubahan-perubahan usaha mengembalikan koperasi sesuai dengan fungsinya, antara lain:

a) Menghidupkan kembali dasar-dasar demokrasi

b) Menegakkan pengertian swadaya pada koperasi yang memerlukan kebebasan untuk bergerak dan pembinaan pemerintah lebih bersifat Tut Wuri Handayani.

c) Menyusun kebijaksanaan-kebijaksanaan yang ebrsifat motivasi

d) Menyiapkan Undang-undang koperasi yang baru untuk menggantikan Undang-undang Nomor 14 tahun 1965.

Sampai dengan tahun 1966 di Indonesia terdapat 73.406 perkumpulan koperasi dengan anggota 11.775.930. dengan berlakunya Undang-undang nomor 12/1967, tentang pokok-pokopk perkoperasian dan berubahnya pola kebijaksanan ekonomi, koperasi mengalami rasionalisasi yang drastis. Sedangkan koperasi-koperasi yang tidak menyesuaikan dengan Undangundang tersebut mengalami kehancuran, sehingga sampai dengan tahun 1968, jumlah koperasi hanya 14.749 dengan jumlah anggota 3.540. 671 orang. Pada tahun 1073, ditetapkan Inpres No. 4 tahun 1973 memperkuat kedudukan koperasi sebagai perusahaan, khususnya koperasi di daerah yang potensinya sebagian besar berasal dari sector pertanian. Dalam Inpres No. 4 tahun 1973 ditentukan bahwa kegiatan dalam wilayah unit desa dapat dilaksanakan KUD antara lain:

a) Penyaluran sarana produksi untuk kepentingan par apetani dalam meningkatkan produksi

b) Mengolah dan memasarkan hasil usaha para petani 
Pola pembinaan yang dilakukan pemerintah terhadap koperasi adalah sebagai berikut:

a) Pola pembinaan umum, yaitu pembinaan yang mengutamakan bimbingan, pengawasan, organisasi dan manajemen

b) Pola pembinaan BUUD/KUD yang mengutamakan pembinaan koperasi yang dikaitkan langsung dengan pembanguna pedesaan.

Pembinaan koperasi oleh pemerintah semakin dimantapkan sampai dengan berlakunya Inpres No. 4/1984 yang memberikan kepercayaan kepada warga desa untuk membentuk KUD oleh warga desa suatu desa atau kelompok desa yang disebut unit desa yang merupakan kesatuan ekonomi masyarakat kecil.

Kedudukan perkoperasian dalam pembangunan perekonomian semakin dipercaya samapi berlakunya Undang-undang perkoperasian Nomor 25/1992, sebagai penyempurna Undang-undang No. 12/1967. pembangunan koperasi Indonesia juga termasuk yang dicanangkan dalam tahapan-tahapan pembangunan lima tahun yang pola umumnya tercantum dalam garis-garis besar haluan Negara. Sampai sekarang koperasi terus berkembang pesat, kurang lebih 4.700 koperasi telah berkembang dari berskala kecil, berskala menengah, sampai berskala besar.

\section{Perbedaan Koperasi dengan Badan Usaha Non Koperasi}

Di dalam masyarakat terdapat berbagai macam organisasi kegiatan ekonomi, baik yang dijelaskan pemerintah maupun swasta, melalui badan kooperasi maupun badan usaha non koperasi. Diantara badan usaha non koperasi adalah: Firma, Persekutuan Komanditer, PT, BUMN, Manufacturing, Trading Company, Coporation, Cartel, Trust, dan corcorn. Badan tersebut berbeda dengan koperasi, letak perbedaannya dapat dilihat dari beberapa aaspek, yaitu:

\section{a. Aspek Kelembagaan}

Perbedaan koperasi dengan badan usaha non koperasi dilihat dari aspek kelembagaan. 
Itang: Badan Usaha Koperasi...

1. Dilihat dari segi keanggotaan

Koperasi: yang dapat menjadi anggota koperasi adalah setiap warga Negara Indonesia yang mmapu melakukan tindakan hukum dan mempunyai kepntingan yang serta dalam menentukan kebijaksanaan usaha didasarkan pada satu suara.

Non koperasi: tidak setiap orang bebas menjadi anggota tetapi terbatas pada pemilik modal yang memasukkan modalnya dalam usaha yang dijalankan

2. Dilihat dari rapat anggota

Koperasi: satu anggota satu suara dan tidak dapat diwakilkan pada orang lain Non koperasi: hak suara dalam rapat, seseorang memegang saham dapat mempunyai lebih dari satu suara tergantung pada jumlah saham yang dimiliknya.

3. Dilihat dari kepengurusan Direksi

Koperasi: pengurus dipilih dan oleh anggota koperasi

Non koperasi: direksi adalah pemimpin badan usaha yang dipilih oleh rapat umum, pemilik badan usaha (boleh dipilih oleh bukan pemilik).

4. Dilihat dari Dewan Komisaris

Koperasi: pengawas dipilih oleh dan pengurus anggota koperasi

Non koperasi: Dewan komisaris adalah perwakilan dari pemilik badan usaha, anggotanya pemegang saham yang bertugas mengawasi tindakan direksi dan jalannya badan usaha.

5. Dilihat dari manajemennya

Koperasi: berdasarkan prinsip demokrasi

Non koperasi: berdasarkan atas saham yang dimiliki, satu saham saut suara. Pemberian suara dengan proxy dibolehkan.

6. Dilihat dari pendidikan

Koperasi: menyelenggarakan pendidikan bagi anggotanya

Non koperasi: pendidikan hanya ada kalau menguntungkan secara material bagi badan usaha. 


\section{b. Aspek Usaha}

Perbedaan aspek usahanya yaitu:

1. Tujuan

Koperasi: tidak semata-mata mencari keuntungan, melainkan mencari perbaikan hidup dan kesejahteraan anggotanya.

Non koperasi: tujuan mencari laba yang setinggi-tingginya.

2. Modal

Koperasi: modal adalah sebagai alat. Keuntungan yang diperoleh dibagi kepada anggotanya menurut jasa masing-masing.

Non koperasi: modal adalah primer, orang adalah skunder. Jumlah modal menentukan besarnya hak suara dan keuntungan dibagi menurut besar kecilnya modal.

3. Badan Hukum

Koperasi: biasanya tunduk pada UU. Tentang perkoperasian

Non koperasi: tunduk pada KUHD dan pendaftaraannya pada pengadilan negeri.

4. Aspek Keuntungan

Koperasi: pada dasarnya koperasi tidak mementingkan keuntungan Karena tujuan utamanya adalah memajukan kesejahteraan anggota dan masyarakat. Bukan berarti keuntungan tidak penting, kerena keuntungan adalah salah satu sarana untuk mencapai tujuan tersebut. Dalam koperasi keuntungan lebih dikenal dengan sisa hasil usaha merupakan pendapatan koperasi yang diperoleh dalam satu tahun bukan dikurangi dengan biaya penyusutan dan kewajiban lainnya termasuk pajak dan tahun buku yang bersangkutan. Non koperasi: badan usaha non koeprasi merupakan konsentrasi-konsentrasi modal, dan maju mundurnya badan usaha sangat bergantung pada modal tersebut, sehingga tujuan utamanya adalah mengejar keuntungan yang sebesar-besarnya. Keuntungan yang diperoleh dibagikan sebanding dengan modal yang dimasukkan ke dalam perusahaan.

\section{Kesimpulan}

Perbedaan badan usaha non koeprasi dapat dilihat dari beberapa aspek, yaitu: a. Aspek kelembagaan, yaitu: 1. Dilihat dari segi keanggotaan, 2. Dilihat dari rapat anggota, 3. Dilihat dari kepengurusan Direksi, 4. Dilihat dari Dewan Komisaris, 5. 
Itang: Badan Usaha Koperasi...

Dilihat dari manajemen, 6. Dilihat dari pendidikan. b. Aspek usaha, yaitu: 1. Tujuan, 2.

Modal, 3. Badan Hukum, 3. Aspek Keuntungan, yaitu: Koperasi: pada dasarnya koperasi tidak mementingkan keuntungan Karena tujuan utamanya adalah memajukan kesejahteraan anggota dan masyarakat. Bukan berarti keuntungan tidak penting, kerena keuntungan adalah salah satu sarana untuk mencapai tujuan tersebut. Dalam koperasi keuntungan lebih dikenal dengan sisa hasil usaha merupakan pendapatan koperasi yang diperoleh dalam satu tahun bukan dikurangi dengan biaya penyusutan dan kewajiban lainnya termasuk pajak dan tahun buku yang bersangkutan. Non koperasi: badan usaha non koeprasi merupakan konsentrasi-konsentrasi modal, dan maju mundurnya badan usaha sangat bergantung pada modal tersebut, sehingga tujuan utamanya adalah mengejar keuntungan yang sebesar-besarnya. Keuntungan yang diperoleh dibagikan sebanding dengan modal yang dimasukkan ke dalam perusahaan.

\section{Pustaka Acuan}

Arifinal Chanoago, Koperasi Indonesia, Angkasa Bandung1979:1

Datta Wardhana, dkk, Pelajaran Koperasi dan Cara Menyelenggarakan Koperasi Sekolah, Aries Lima, Jakarta , 1986:19

Departemen Koperasi, Pengetahuan Koperasi, Jakarta, 1985: 72

Hendrojogi, Koperasi Azas-azas dan Praktek, PT. Raja Grafindo Persada, Jakarta, 1997:19.

J.K. Lumunon, pengetahuan Perkoperasian, Departemen Perdagangan dan Koperasi Direktorat Jendral Koperasi, Jakarta, t.t :26

John M. Echols, Kamus Inggris Indonesia, Penerbit PT. Gramedia Jakarta, 1994:147. "Cooperation" berubah dalam dialek bahasa Indonesia menjadi koperasi (Muhammad Ali, Kamus Lengkap Bahasa Indonesia Moderen Penerbit Pustaka Amani Jakarta, t.t:1997).

Kansil, Pengantar Ilmu Hukum dan Tata Hukum di Indonesia, Balai Pustaka, Jakarta , 1989:29.

Kaslan A. Tohir, Pelajaran Koperasi, PN. Balai Pustaka, Jakarta, 1964:19.

Margono Djojohadi Joesomo, 10 tahun koperasi: Penerangan Tentang Koperasi Oleh Pemerintah 1930-1940, Balai Puastaka, Batavia-C, 1941:20. 
Islamiconomic: Jurnal Ekonomi Keuangan dan Bisnis Islam Vol.7 No.1 Januari - Juni 2016

Ninik Widiyanti, dkk. Koperasi dan Perekonomian Indonesia, Bina Aksara, Jakarta, 1989:1.

Parjimin Nurjain, dkk. Buku Materi Pokok Perkoperasian, ADNE 4330/2SKS/Modul 13, Karunika, Jakarta, Universitas Terbuka, 1986:12.

Peraturan umum tentang koperasi (Staatsblad 1933 No. 108), (Subekti, Pokok-pokok Hukum Perdata, Intermamasa Jakarta, 1991:12).

Pidato pertanggung Jawaban Presiden R.I. H. Mohammad Soeharto. Pada hari Minggu, tanggal 1 Maret 1998.

Printono, Koperasi dalam Ekonomi Pembangunan, CV. "Duar”, Bandung, t.t.: 5.

SOejono Soekanto, Sosiologi Suatu Pengantar, Grafindo Persada, Jakarta, 1995:124125).

Sri-Edi Swasono, Koperasi di Dalam Orde Ekonomi Indonesia, UI-Press Jakarta 1987:159.

Sriyono, Ekonomi dan Koperasi, PT. Pabelan, Surakarta, 1995:83-84

Sugimun, MD. Dkk. Indonesia Berkoperasi, PN. Balai Pustaka, Jakarta, 1983:17

Sugimun, MD. Koperasi Indonesia, CV. Haji Masagung Jakarta. 1920:2.

UU Koperasi No. 25/1992 Tentang Pokok-pokokperkoperasia, CV. Sinar Grafika Jakarta 1993:12.

\section{Catatan Akhir:}

${ }^{1}$ John M. Echols, Kamus Inggris Indonesia, Penerbit PT. Gramedia Jakarta, 1994:147. “Cooperation” berubah dalam dialek bahasa Indonesia menjadi koperasi (Muhammad Ali, Kamus Lengkap Bahasa Indonesia Moderen Penerbit Pustaka Amani Jakarta, t.t:1997).

2 Printono, Koperasi dalam Ekonomi Pembangunan, CV. “Duar”, Bandung, t.t.: 5.

${ }^{3}$ Hendrojogi, Koperasi Azas-azas dan Praktek, PT. Raja Grafindo Persada, Jakarta, 1997:19.

4 Margono Djojohadi Joesomo, 10 tahun koperasi: Penerangan Tentang Koperasi Oleh Pemerintah 1930-1940, Balai Puastaka, Batavia-C, 1941:20.

5 Hendrojogi, Koperasi Azas-azas dan Praktek, Op. Cit. h. 22- 23.

${ }^{6}$ Arifinal Chanoago, Koperasi Indonesia, Angkasa Bandung1979:1

${ }^{7}$ Sugimun, MD. Dkk. Indonesia Berkoperasi, PN. Balai Pustaka, Jakarta, 1983:17

${ }^{8}$ Sugimun, MD. Koperasi Indonesia, CV. Haji Masagung Jakarta. 1920:2.

${ }^{9}$ Ir. Kaslan A. Tohir, Pelajaran Koperasi, PN. Balai Pustaka, Jakarta, 1964:19.

${ }^{10}$ Departemen Koperasi, Pengetahuan Koperasi, Jakarta, 1985: 72

${ }^{11}$ Sri-Edi Swasono, Koperasi di Dalam Orde Ekonomi Indonesia, UI-Press Jakarta 1987:159.

12 UU Koperasi No. 25/1992 Tentang Pokok-pokokperkoperasia, CV. Sinar Grafika Jakarta 1993:12. Peraturan umum tentang koperasi (Staatsblad 1933 No. 108), (Subekti, Pokok-pokok Hukum Perdata, Intermamasa Jakarta, 1991:12).

${ }^{13}$ Ninik Widiyanti, dkk. Koperasi dan Perekonomian Indonesia, Bina Aksara, Jakarta, 1989:1.

${ }^{14}$ Hendrojogi, Koperasi Azas-azas, Teori dan Praktek, Op. Cit. h. 20-21

15 Undang-undang No. 25/1992, Op. Cit. h. 12 
Itang: Badan Usaha Koperasi...

${ }^{16}$ Parjimin Nurjain, dkk. Buku Materi Pokok Perkoperasian, ADNE 4330/2SKS/Modul 1-3, Karunika, Jakarta, Universitas Terbuka, 1986:12.

17 Sebab manusia makhluk ZOON POLITICON artinya manusia pada dasarnya selalu ingin bergaul dan berkumpul dengan sesama manusia lainnya (Kansil, Pengantar Ilmu Hukum dan Tata Hukum di Indonesia, Balai Pustaka, Jakarta, 1989:29).

18 Yaitu Keingina untuk menjadi satu dengan manusia lain disekelilingnya dan keinginan untuk menjadi satu dengan suasana alam sekelilingnya (SOejono Soekanto, Sosiologi Suatu Pengantar, Grafindo Persada, Jakarta, 1995:124-125).

${ }^{19}$ Ninik Widiyanti, Op. Cit. h. 2-3

${ }^{20}$ Sugimun, dkk. Indonesia Berkoperasi, Op. Cit. h. 36

21 J.K. Lumunon, pengetahuan Perkoperasian, Departemen Perdagangan dan Koperasi Direktorat Jendral Koperasi, Jakarta, t.t :26

${ }^{22}$ Sugimun, MD, Koperasi Indonesia, Op. Cit. h. 23

23 J.K. Lumunon, Op.Cit. h. 26

24 Drs. Datta Wardhana, dkk, Pelajaran Koperasi dan Cara Menyelenggarakan Koperasi Sekolah, Aries Lima, Jakarta , 1986:19

${ }^{25}$ J.K Lumunon, Op. Cit. h. 27 
Islamiconomic: Jurnal Ekonomi Keuangan dan Bisnis Islam Vol.7 No.1 Januari - Juni 2016 